she was fitted with an inclined direct-acting lowpressure engine of 90 nominal h.p., constructed by Stephen Vail, at the Speedwell Iron Works, near Morristown, New Jersey. There was one cylinder $40 \mathrm{in}$. in diameter by $5 \mathrm{ft}$. stroke. The paddle-wheels were made detachable, so that they could be taken on deck when not in use. The Sarannah sailed from the port of that name on May 24, 1819 ; she was off the coast of Ireland on June 17, and arrived in Liverpool three days later. Other accounts state that the Sarannah arrived in Cork harbour with insufficient coal to raise steam, and that most of her Atlantic crossing was made under sail alone, doubtless with the paddle-wheels on deck. The Museum has also acquired an early machine for covering wires with silk and cotton used from about 1837. It was at one time owned by Mr. W. T. Henley, a pioneer in this field, and was probably made by him. It is still in workable condition.

\section{Roman York: A Recent Discovery}

Is the course of carrying out a municipal scheme of improvement, further remains of the fortifications of Roman York have been brought to light, which, it would appear, are part of the curtain wall erected by the emperor Constantinus Chlorus in the fourth century to strengthen the fortifications of the city against the attacks of pirates coming up the river (The Times, July 11). In driving an arcade through Coney Street, the remains of an internal tower were discovered which was built astride the wall, and was not external as towers previously rovealed had proved to be. Its walls are of dressed stone, and on the south side stand to a height of nearly four feet. On the north side are the remains of what would appear to be a pier of dressed stone, three feet high and connected with the main wall by layers of stone slabs. This is believed to have been either the support of a platform of the tower, or the pier of a bridge, carrying the rampart walk over the interval formed by the tower. Remains of the cobbled rampart walk, with the foundations of another building on the east side, have been found. The position of the tower corresponds with what has hitherto been believed to be the character of the curtain wall, where it ran from the Multangular Tower to the angle tower at the south-east corner of the junction of Coney Street and Market Street. It is the fourth interval tower that has been found.

\section{Anglo-Saxon Burials in Rutland}

To a largo number of scattered burials forming an Anglo-Saxon cemetery in a pit at North Luffenham, Rutland, belonging to Mr. A. H. Lewis of Morcot, have now been added the graves of a man and woman, in which the male skeleton presents the unusual but not unknown feature in an Anglo-Saxon burial of the period of being in the crouched position (The Times, July 11). The grave furniture in this burial consisted of a spear, a pottery bowl, and a large bronze bowl, much crushed. All traces of the woman's body had disappeared, but the grave contained a spindle-whorl, a pot, some beads and a glass bottle.
The spear is an unusually long specimen of the 'angular' type, the blade measuring $10 \frac{1}{2}$ inches. A fragment of the shaft is still embedded in the head. The bronze bowl, the most notable object found, belongs to a well-known type of the pagan AngloSaxon period. It is a wide elliptical dish, $16 \frac{1}{2}$ inches by $12 \frac{1}{2}$ inches, with a depth of about $6 \frac{1}{2}$ inches. A horizontal projecting flange is about an inch in width, and on it is embossed a continuous series of studs. The foot ring, of $4 \frac{1}{2}$ inches diameter, is cast separately. The bowl has been repaired twice near the rim by the addition of small strips of metal riveted over cracks.

\section{The Golden Gate Bridge, San Francisco}

Engineering of July 7 contains tho first of a series of articles on the Golden Gate Bridge, San Francisco, by Mr. C. E. Paine, who acted as principal assistant engineer during its construction. This bridge, which was opened in May 1937, is notable as having the longest suspension span of any bridge yet erected, the length of the span being $4,200 \mathrm{ft}$. as against the $3,500 \mathrm{ft}$. of the Hudson River Bridge built in 1931 . Its side spans are $1,125 \mathrm{ft}$. long, giving a total sus. pended structure of $6,450 \mathrm{ft}$. The two supporting towers are $690 \mathrm{ft} .4 \mathrm{in}$. from the top of the piers to the bottom of the saddles and have a combined weight of 35,178 tons, while the wire cables are each over 36 inches in diameter and contain 27,572 steel wires $0 \cdot 195$ inches in diameter, arranged in 61 strands. The roadway across the bridge is $60 \mathrm{ft}$. wide, giving room for six lines of motor traffic, and there are two side-walks $10 \mathrm{ft}$. wide. The dead load of the main span per lineal foot is 9.51 tons and the live load allowed for is 1.78 tons per lineal foot. The bridge leads from San Francisco to a district ideal for suburban dovelopment and for recreational purposes, and it has closed almost the last break in the two thousand miles long coast road which extends from Canada to Mexico. The American Institute of Steel Construction selected the Golden Gate Bridge as the most beautiful bridge, costing more than $1,000,000$ dollars, completed in the United States in the year 1937.

\section{The L.C.C. as an Electricity Consumer}

Is a recent paper read before the Association of Supervising Electrical Engineers by Mr. Forbes Jackson, the quantity of electricity consumed by the London County Council and the difficulty experienced in reducing its cost aro discussed. The area of the L.C.C. is 116 square miles, and it has a population of more than four million. It consumes approximately for its own services, including drainage, schools, hospitals, fire brigades and administrative buildings, 35 million electric units a year. As this supply is taken from 1,100 different points and from various supply authorities, it is not able to reap the benefit of its great diversity of supply and get an inclusive tariff. This is perhaps the reason why electric supply is not more largely used. Mr. Forbes says that there are only three hospitals which use electric cooking, and its use is not increasing. The L.C.C. deals 